\title{
PRODUCTION AND MARKETING OF ORGANIC COFFEE IN NEPAL
}

\author{
J. Pandit ${ }^{1}$, J.P. Dutta ${ }^{2}$, P.P Regmi ${ }^{3}$ and S.M. Shakya ${ }^{3}$ \\ ${ }^{1}$ Department of Livestock Services (DLS), Ministry of Agriculture Development (MOAD), \\ Nepal ${ }^{2}$ Agriculture and Forestry University, Chitwan, Nepal, ${ }^{3}$ Institute of Agriculture and Animal \\ Sciences, Tribhuvan University, Nepal.
}

\begin{abstract}
A survey research was carried out in 2008 in Kavrepalanchok, Sindhupalchok, Gulmi, Palpa and Syangja districts and Kathmandu valley to analyze the factors affecting coffee production and analyze the present marketing systems of coffee. One coffee producers' group from each district was selected. All coffee growers of these selected groups were taken as sample. Altogether, 132 coffee growers were interviewed. For marketing information, 4 processors and traders were also interviewed. Manure, organic solution and labor were using for coffee production. The average variable cost of production was maximum in Syangja, which was Rs 85604.83 per ha. Gross margin and benefit cost ratio of coffee production were maximum in Syangja, which were Rs 176173.57 per ha and 2.71, respectively. The number of productive plant was the significant factor affecting production in Kavrepalanchok, Sindhupalchok, Palpa and Syangja. Labor was the significant factor affecting production in Sindhupalchok, Gulmi, Palpa and Syangja. Marketing margin was Rs 52.88 and Rs 50.46 per kg of fresh cherry in the form of roasted bean and ground coffee, respectively. Producers' share of fresh cherry after processed to roasted bean and ground coffee was 32.96 percent and 34.00 percent, respectively.
\end{abstract}

Key Words: Organic coffee, benefit cost ratio, marketing

\section{INTRODUCTION}

Coffee is cash crop started to be grown in Nepal almost with no use of inorganic fertilizer and pesticide (AEC, 2006). Coffee contributes about 0.04 percent to GDP of Nepal (PSS, 2004). It provides 5 times more yield than that of maize and millets and 2-3 times more yield than that of any other cash crops (Dhakal, 2004). At present, available statistics indicate that coffee is being cultivated commercially in twenty-one districts of Nepal (NARC, 2004). It could be an important occupation in the rural economies with massive participation of marginal, poor and down trodden class of rural communities (AEC, 2006).

It is the second most valuable legally traded commodity in the world after oil (Dhakal, 2005). It is a high value cash generating crop for hill farmers of Nepal (Khanal, 2003). Nepal is endowed with provable climatic and soil conditions to produce good quality coffee "specialty coffee" above 800 to 1400 masl (Dhakal, 2005). The demand of organic and specialty coffee with reduced amount of caffeine is increasing in the world market (Dhakal, 2005). Hence, it can compete easily in the international market and holds a special place as a foreign exchange earner for Nepal.

Nepal became the $147^{\text {th }}$ member of the WTO in April, 2004 (Adhikari, 2005). In the context of globalization and free trade, there are several opportunities in the export of high value commodities like coffee at relatively cheaper cost of production. By utilizing the comparative resource advantage, Nepal could compete for quality coffee production in the world. So, this study may help to identify the new way for the development of coffee sector in the mid hills of Nepal where most of the poor 
and marginalized sections of people reside, through increased productivity and improved quality with exploration of export potentiality.

There is inadequate research carried out till date in the production and marketing aspects of coffee in Nepal. The findings of this study will help to develop a strategy towards the commercialization of coffee sectors in Nepal.

The objective of this study was to analyze the factors affecting coffee production and analyze the present marketing systems of coffee.

\section{RESEARCH METHODOLOGY}

Kavrepalanchok, Sindhupalchok, Gulmi, Palpa and Syangja districts were selected due to pocket area for production and from market modality perspective. One coffee producers' group from each district i.e. from Panchkhal VDC of Kavrepalanchok, Sangachok VDC of Sindhupalchok, Baletaxar VDC of Gulmi, Madanpokhara VDC of Palpa and Bahakot VDC of Syangja were taken. All the coffee growers of these selected coffee producers' groups constitute sample population. Altogether, 132 coffee growers consisting 37 from Kavrepalanchok, 25 from Sindhupalchok, 22 from Gulmi, 24 from Palpa and 24 from Syangja were selected as sample. For marketing information, 4 major coffee processors and traders, from Kathmandu (3) and Palpa (1) were selected. Similarly, retailers in Kathmandu valley which included departmental stores and supermarkets consisting 3 and 2 were taken, respectively. Primary data was collected through pre-tested interview schedule and other relevant information was taken from the secondary sources. Coffee growers, coffee processors and traders, retailers, observation, group discussion and key informants, were the primary sources of information. Different institutions and organizations related to coffee sector were the secondary source of information. Both the primary and secondary information collected coded, tabulated and analyzed by using Statistical Package for Social Sciences (SPSS) and Micro-Soft Excel. In methodology section, following analysis were conducted.

\section{Cost of production}

Only variable cost items were included for analyzing the cost of production. The variable cost included manure cost, cost of organic solution and labor cost for different production activities. Cost of organic solution was calculated as labor cost required for its preparation.

\section{Gross margin analysis}

It is the difference between total value product and variable cost associated to particular enterprise. The gross margin of the coffee production was calculated as:

Gross margin $=$ Gross return - Total variable cost

Where, gross return $=$ price of fresh cherry*total quantity sold

Total variable cost $=$ Summation of cost of all variable items

\section{Profit analysis}

The profit is the difference between total revenue and the total cost incurred. Total cost included fixed cost and variable cost. Cost accrued to fixed costs included - depreciation in fixed assets like coffee plant and different implements used for its production. Thus, the net profit can be written as:

$$
\begin{aligned}
& =\mathrm{TR}-\mathrm{TC} \\
& =\mathrm{TR}-(\mathrm{TFC}+\mathrm{TVC}) \\
& =\mathrm{Py}{ }^{*} \mathrm{Y}-\mathrm{Pxi}^{*} \mathrm{X}-\mathrm{K}
\end{aligned}
$$


Where,
$\Pi=$ Net profit
$\mathrm{TR}=$ total revenue
$\mathrm{TC}=$ total cost,
$\mathrm{TFC}=$ total fixed cost,
$\mathrm{TVC}=$ total variable cost,
$\mathrm{Y}=$ quantity of output,
$\mathrm{X}_{\mathrm{i}}=$ quantity of $\mathrm{i}^{\mathrm{th}}$ input,
$\mathrm{P}_{\mathrm{y}}=$ price of output
$\mathrm{PXi}_{\mathrm{X}}=$ price of $\mathrm{i}^{\text {th }}$ input
$\mathrm{K}=$ fixed cost

\section{Benefit-Cost analysis}

For the benefit cost analysis, the total cost of coffee production including fixed cost and variable cost, and total return from coffee production was used.

Benefit: Cost ratio $=$ Total return/Total Cost

\section{Factors affecting production of coffee}

The Cobb-Douglas production function was used to find out the variables that affect the production of coffee. Mathematically, the model was expressed as:

$\mathrm{Y}=\alpha \mathrm{X}^{1} \mathrm{~b}^{1} \mathrm{X}^{2} \mathrm{~b}^{2} \mathrm{X}^{3} \mathrm{~b}^{3} \mathrm{X}^{4} \mathrm{~b}^{4}$

In $\log$ linear form, the above model can be expressed as follows:

$\operatorname{InY}=\operatorname{In} \alpha_{0}+\operatorname{In} X_{1}+\operatorname{In} X_{2}+\operatorname{In} X_{3}+\operatorname{In} X_{4}$

Where,

$\mathrm{Y}=$ Total coffee yield

$\mathrm{X}_{1}=$ Area under coffee cultivation,

$\mathrm{X}_{2}=$ Labor used

$\mathrm{X}_{3}=$ Number of productive plants,

$\mathrm{X}_{4}=$ Manure used

$\alpha_{0}=$ coefficient to be estimated

\section{Marketing margin and producers' share}

Marketing margin is the difference between the farm gate price and the retailer's price, which was calculated as follows: Marketing margin $(\mathrm{MM})=\mathrm{P}_{\mathrm{r}}-\mathrm{P}_{\mathrm{f}}$

Producers' share is the price received by the farmer expressed as a percentage of the retail price, that is, the price paid by the consumers. Producers' share $\left(\mathrm{P}_{\mathrm{s}}\right)=\left(\mathrm{P}_{\mathrm{f}} / \mathrm{P}_{\mathrm{r}}\right) \times 100$

Where, $\mathrm{P}_{\mathrm{f}}=$ Producer's price (farm gate price), $\mathrm{P}_{\mathrm{r}}=$ Retailer's price,

\section{RESULT AND DISCUSSION}

The collected information was analyzed as per objective using proper statistical tool and the results have been presented in this section.

\section{Cost of production and return}

Organic manures like FYM, vermi-compost, organic solution and labor were used for coffee production. Organic solution was prepared by coffee growers using locally available plants and other materials which are presented in appendix 1. Similar case was reported by ABTRACO (2004) in Palpa, Nepal. The study done by ABTRACO revealed that inputs used by coffee grower are organic manure and organic pesticides.

Table 1 shows that the average variable cost of production was highest in Syangja (85604.83 Rs/ha) and lowest in Palpa (63324.10 Rs/ha). The highest variable cost of production in Syangja was simply because of more inputs used such as organic manure and labors in Syangja. The average return was maximum in Syangja (261778.40 Rs/ha) and minimum in Palpa (182453.80 Rs/ha). The 
higher return in Syangja might be due to higher productivity which might be due to use of more inputs

Table 1. Cost of production and return (Rs/ha) from coffee by districts (2008)Districts

\begin{tabular}{lll}
\hline Districts & Variable Cost $(\mathrm{Rs} / \mathrm{ha})$ & Return $(\mathrm{Rs} / \mathrm{ha})$ \\
\hline Kavre $(\mathrm{n}=37)$ & 67296.52 & 207281.30 \\
Sindhu $(\mathrm{n}=25)$ & 75950.04 & 233806.60 \\
Gulmi $(\mathrm{n}=22)$ & 66204.70 & 197001.50 \\
Palpa $(\mathrm{n}=24)$ & 63324.10 & 182453.80 \\
Syangja $(\mathrm{n}=24)$ & 85604.83 & 261778.40 \\
\hline Total $(\mathrm{N}=132)$ & 71676.04 & 216464.32 \\
\hline
\end{tabular}

\section{Gross margin analysis}

Table 2 shows that the average gross margin was highest in Syangja (Rs 176173.57/ha) and lowest in Palpa (Rs 119129.70/ha). High gross margin in Syangja might be due to higher production compared to other districts. The overall gross margin was found to be Rs 144788.34 per ha. The analysis of gross margin showed that coffee cultivation was more profitable in Syangja as compared to other districts under study.

Table 2. Gross margin analysis (Rs/ha) of coffee production by districts (2008).

\begin{tabular}{ll}
\hline Districts & Gross margin $(\mathrm{Rs} / \mathrm{ha})$ \\
\hline Kavre $(\mathrm{n}=37)$ & 139984.78 \\
Sindhu $(\mathrm{n}=25)$ & 157856.56 \\
Gulmi $(\mathrm{n}=22)$ & 130796.80 \\
Palpa $(\mathrm{n}=24)$ & 119129.70 \\
Syangja $(\mathrm{n}=24)$ & 176173.57 \\
\hline Total $(\mathrm{N}=132)$ & 144788.34 \\
\hline
\end{tabular}

\section{Profit and benefit cost ratio analysis}

The net net profit from coffee cultivation was highest in Syangja (165354.72 Rs/ha) and lowest in Palpa (108949.62 Rs/ha) as shown in table 3. Highest net profit in Syangja might be due to highest production of coffee. The highest net profit in Syangja indicated that coffee cultivation was more profitable in Syangja due to higher use of organic inputs. Similar case was reported by (Sarcinelli and Ortega, 2004) in Brazil. They found that $29.8 \%$ profitability (i.e. 536.9 US\$ net profit $/$ ha/yr) was obtained in case of organic coffee production system and 16.9\% (318.3 US\$ net profit/ha/yr) profitability was obtain in case of conventional coffee production system.

Table 3. Net profit (Rs/ha) and benefit cost ratio of coffee production by districts (2008)

\begin{tabular}{lllll}
\hline \multicolumn{1}{c}{ Districts } & Return $(\mathrm{Rs} / \mathrm{ha})$ & Total cost $(\mathrm{Rs} / \mathrm{ha})$ & Net profit $(\mathrm{Rs} / \mathrm{ha})$ & $\mathrm{B} / \mathrm{C}$ ratio \\
\hline Kavre $(\mathrm{n}=37)$ & 207281.30 & 78153.54 & 129127.76 & 2.65 \\
Sindhu $(\mathrm{n}=25)$ & 233806.60 & 86495.92 & 147310.68 & 2.70 \\
Gulmi $(\mathrm{n}=22)$ & 197001.50 & 75986.36 & 121015.14 & 2.59 \\
Palpa $(\mathrm{n}=24)$ & 182453.80 & 73504.18 & 108949.62 & 2.48 \\
Syangja $(\mathrm{n}=24)$ & 261778.40 & 96423.68 & 165354.72 & 2.71 \\
\hline Total $(\mathrm{N}=132)$ & 216464.32 & 82112.74 & 134351.58 & 2.64 \\
\hline
\end{tabular}


Also, the benefit cost ratio was highest in Syangja (2.71) and lowest in Palpa (2.48) which is shown in table 3. The overall benefit cost ratio was 2.64. There was slight difference in benefit cost ratio in all five districts, which was attributed to differences of price of fresh cherry and labor wage rate. The highest benefit cost ratio indicated that coffee cultivation was prominently profitable enterprise in Syangja. However, greater than 1 benefit cost ratio also indicated that coffee cultivation was running in profit in other districts too.

\section{Factors affecting production of coffee}

Table 4 indicates that the number of productive plants was the most significant factor affecting production of coffee in Kavrepalanchok. The output elasticities of number of productive plant was 0.816 indicating that holding the other explanatory variables constant, one percent change in number of productive plant contributed 0.816 percent increase in output. The summation of all values of parameter was 0.975 , which indicated the decreasing returns to scale.

Table 4. Factors affecting production of coffee in Kavrepalanchok (2008)

\begin{tabular}{lllll}
\hline Variables & $\begin{array}{l}\text { Unstandardized } \\
\text { Coefficients }\end{array}$ & $\begin{array}{l}\text { Standardized } \\
\text { Coefficients }\end{array}$ & $\begin{array}{l}\text { Standard } \\
\text { error }\end{array}$ & P value \\
\hline Constant & 1.242 & & .806 & .133 \\
Number of productive plant & $.816^{* *}$ & .611 & .237 & .002 \\
Area under coffee cultivation & -.175 & -.120 & .193 & .371 \\
Labor & .268 & .280 & .165 & .115 \\
Manure & .066 & .064 & .166 & .695 \\
\hline
\end{tabular}

$\mathrm{R}^{2}=.672$, Adjusted $\mathrm{R}^{2}=.631, \mathrm{~F}$ ratio $=16.382 * *$, and Returns to scale $=0.975$

** and * indicates 1 and 5 percent level of significance

Table 5 reveals that the number of productive plant and labor were the significant factors affecting production of coffee in Sindhupalchok. The output elasticities of number of productive plant and labor were 0.435 and 0.837 indicating that holding the other explanatory variables constant, one percent change in respective plant and labor contributed 0.435 and 0.837 percent increase in output. The summation of all the values of parameters was 0.986 , which indicated the decreasing returns to scale.

Table 5. Factors affecting production of coffee in Sindhupalchok (2008)

\begin{tabular}{lllll}
\hline Variables & $\begin{array}{l}\text { Unstandardized } \\
\text { Coefficients }\end{array}$ & $\begin{array}{l}\text { Standardized } \\
\text { Coefficients }\end{array}$ & $\begin{array}{l}\text { Standard } \\
\text { error }\end{array}$ & P value \\
\hline Constant & 2.301 & & .782 & .008 \\
Number of productive plant & $.435^{*}$ & .329 & .164 & .016 \\
Area under coffee cultivation & -.164 & -.104 & .244 & .511 \\
Labor & $.837^{* *}$ & .832 & .109 & .000 \\
Manure & -.122 & -.173 & .087 & .177 \\
\hline
\end{tabular}

$\mathrm{R}^{2}=.886$, Adjusted $\mathrm{R}^{2}=.863, \mathrm{~F}$ ratio $=38.773^{* *}$, and Returns to scale $=0.986$

** and * indicates 1 and 5 percent level of significance

Table 6 shows that labor was the significant factors affecting production of coffee in Gulmi. The output elasticites of labor was 0.942 indicating that holding the other explanatory variables constant, one percent change in labor contributed 0.942 percent increase in output. The summation of all values of parameters was 0.91 , which indicated the decreasing returns to scale. 
Table 6. Factors affecting production of coffee in Gulmi (2008)

\begin{tabular}{lllll}
\hline Variables & $\begin{array}{l}\text { Unstandardized } \\
\text { Coefficients }\end{array}$ & $\begin{array}{l}\text { Standardized } \\
\text { Coefficients }\end{array}$ & $\begin{array}{l}\text { Standard } \\
\text { error }\end{array}$ & P value \\
\hline Constant & 2.251 & & .932 & .027 \\
Number of productive plant & .465 & .329 & .302 & .142 \\
Area under coffee cultivation & -.262 & -.130 & .264 & .336 \\
Labor & $.942 * *$ & .830 & .189 & .000 \\
Manure & -.235 & -.248 & .114 & .055 \\
\hline
\end{tabular}

$\mathrm{R}^{2}=.869$, Adjusted $\mathrm{R}^{2}=.839, \mathrm{~F}$ ratio $=28.276^{* *}$, and Returns to scale $=0.91$

$* *$ and $*$ indicates 1 and 5 percent level of significance

From table 7, it is evident that the number of productive plant and labor were the highly significant factors affecting production of coffee in Palpa. The output elasticities of number of productive plant and labor were $0.382,0.883$ indicating that holding the other explanatory variables constant, one percent change in respective plant and labor contributed 0.382 and 0.883 percent increase in output. The summation of all the values of parameter was 0.891 , which indicated the decreasing returns to scale.

Table 7. Factors affecting production of coffee in Palpa (2008)

\begin{tabular}{lllll}
\hline Variables & $\begin{array}{l}\text { Unstandardized } \\
\text { Coefficients }\end{array}$ & $\begin{array}{l}\text { Standardized } \\
\text { Coefficients }\end{array}$ & $\begin{array}{l}\text { Standard } \\
\text { Error }\end{array}$ & P value \\
\hline Constant & 2.089 & & .578 & .002 \\
Number of productive plant & $.382^{* *}$ & .325 & .121 & .005 \\
Area under coffee cultivation & -.323 & -.231 & .186 & .098 \\
Labor & $.883^{* *}$ & .903 & .097 & .000 \\
Manure & -.051 & -.082 & .064 & .435 \\
\hline
\end{tabular}

$\mathrm{R}^{2}=.920$, Adjusted $\mathrm{R}^{2}=.905, \mathrm{~F}$ ratio $=57.876^{* *}$, and Returns to scale $=0.891$

** and * indicates 1 and 5 percent level of significance

Table 8 shows that, the number of productive plant and labor were the significant factors affecting production of coffee in Syangja. The output elasticities of number of productive plant and labor were 0.668 and 0.637 indicating that holding the other explanatory variables constant, one percent change in respective plant and labor contributed 0.668 and 0.637 percent increase in output. The summation of all the values of the parameters was 1.054, which indicated the increasing returns to scale.

Table 8. Factors affecting production of coffee in Syangja (2008)

\begin{tabular}{lllll}
\hline Variables & $\begin{array}{l}\text { Unstandardized } \\
\text { Coefficients }\end{array}$ & $\begin{array}{l}\text { Standardized } \\
\text { Coefficients }\end{array}$ & Standard error & P value \\
\hline Constant & 1.379 & & 1.240 & .280 \\
Number of productive plant & $.668^{*}$ & .438 & .326 & .054 \\
Area under coffee cultivation & -.247 & -.171 & .272 & .375 \\
Labor & $.637^{*}$ & .613 & .265 & .027 \\
Manure & -.004 & -.005 & .154 & .978 \\
\hline
\end{tabular}

$\mathrm{R}^{2}=.749$, Adjusted $\mathrm{R}^{2}=.696, \mathrm{~F}$ ratio $=14.194^{* *}$, and Returns to scale $=1.054$

** and * indicates 1 and 5 percent level of significance

The above analysis shows that the return to scale was highest in Syangja and lowest in Palpa. Highest returns to scale in Syangja might be due to optimum utilization of productive resources. 


\section{Marketing system and marketing channels}

Figure 1 shows the marketing channels of coffee in Kavrepalanchok. Similar types of marketing channels were found in Sindhupalchok, Gulmi, Palpa and Syangja. Figure 2 reveals the marketing channels found in Sindhupalchok, Gulmi, Palpa and Syangja. Vibrant root indicates the main marketing channels. However, flow of coffee was found in non-vibrant root however in negligible quantity.

From figure 1 and 2 it is clear that, the producers were selling fresh cherries to the pulping centers. The fresh cherries were depulped, fermented, washed and dried to form dry parchment in the pulping centers. District Coffee Producers Associations (DCPAs) DCPAs of related districts collected the dry parchment and sold it to the processors. However, DCPA, in Kavrepalanchok, was not involved in coffee transaction but played an institutional role. After processing, traders sold the roasted beans and ground coffee in the domestic market in different trade names and prices. But green bean was exported to the international market. Green been was exported by these traders in the international market in the price ranging $4 \$$ to $12 \$$ per $\mathrm{kg}$ of green bean. Thus, the average price fetched by green bean was $8 \$$ (equivalent to Rs 540.80 ).

Most of the coffee produced in Kavrepalanchok and Sindhupalchok districts in 2007 was exported to Japan by Everest Coffee Mills (ECM). District Cooperative Federation, Gulmi (DCF/G) was the trader of coffee in Gulmi district. It had a Co-Operative Coffee Processing Center under its authority. Coffee produced in Gulmi in the year 2007 had been exported to USA, Japan, Korea, Italy and other countries by District DCF/G, Gulmi. DCF/G had already received organic certification from National Association for Sustainable Agriculture, Australia (NASSA). In Palpa and Syangja, Highland Coffee Promotion Company Limited (HCPCL) was the major trader. HCPCL had exported coffee produced in these two districts to Japan, America and European markets in 2007.

From these two figures, it can be concluded that the producers, pulper operators, DCPAs, processors and exporters and retailers were the major actors of coffee marketing in the study areas.

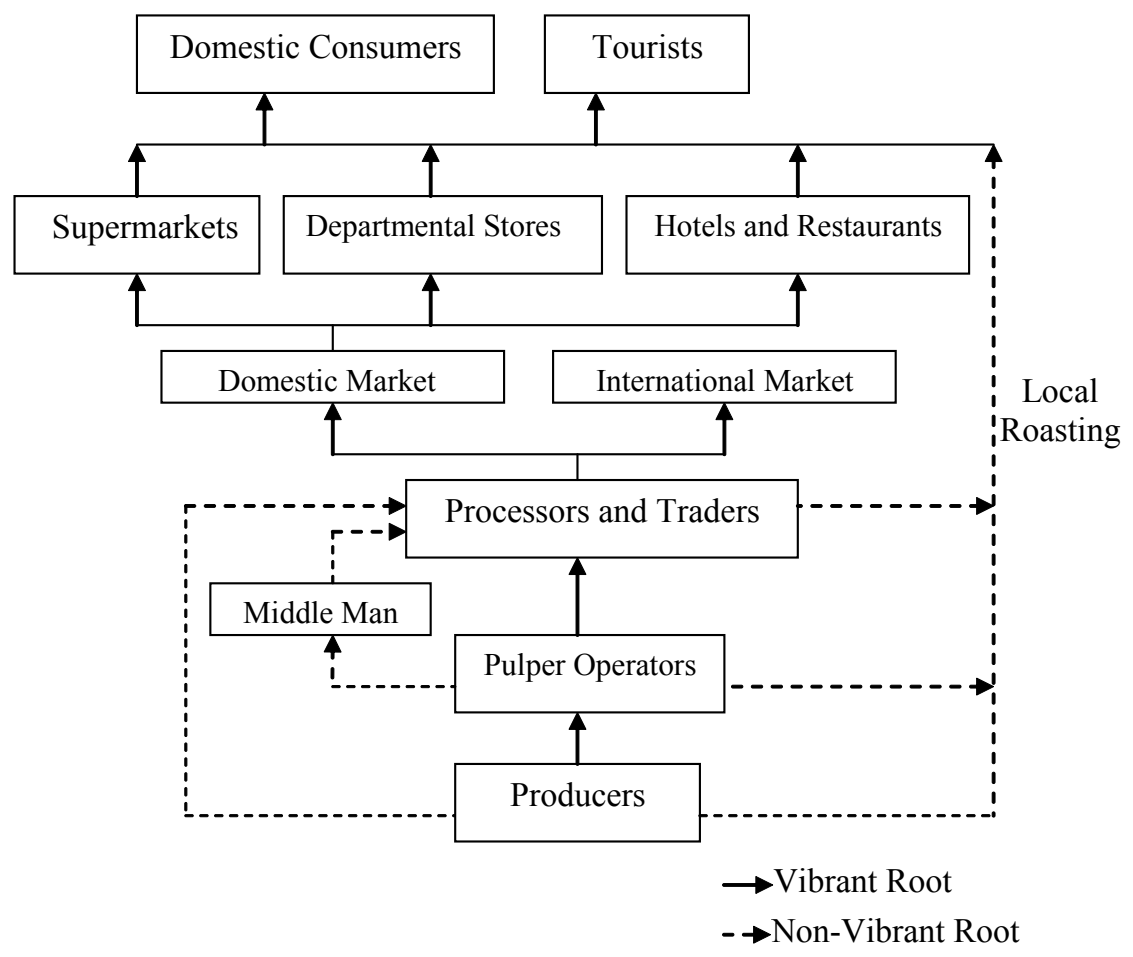

Figure 1: Marketing channels of coffee in Kavrepalanchok 


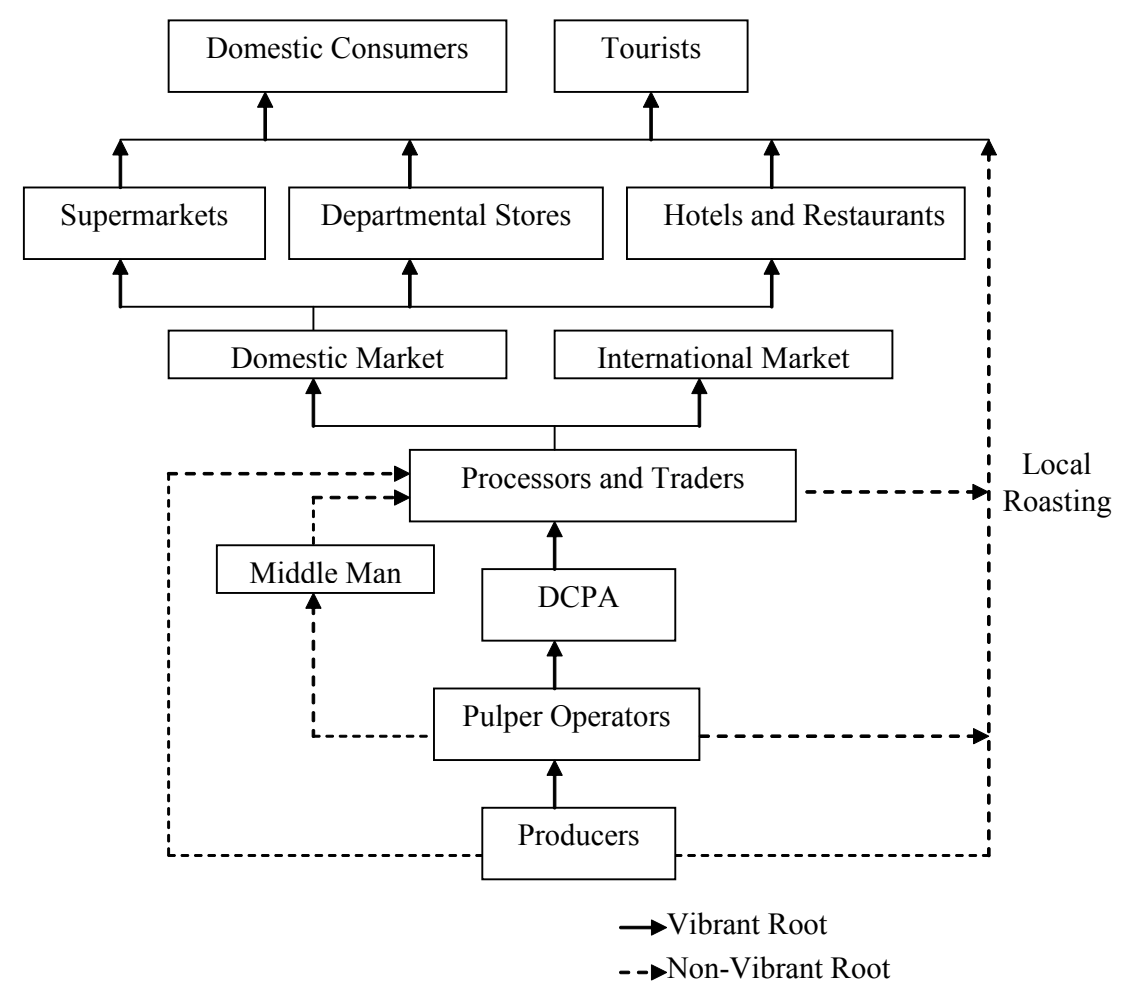

Figure 2: Marketing channels of coffee in Sindhupalchok, Gulmi, Palpa and Syangja

\section{Marketing margin and producers' share}

Processing activities of all 4 processors and traders were same. The average processing cost to make fresh cherry in the form of ground coffee was Rs 76.33 per kg, packaging cost was Rs 14.55 per $\mathrm{kg}$ and marketing cost was Rs 12.99 per kg. Altogether processing and marketing cost accounted Rs 103.87 per kg. The price of ground coffee ranged from Rs 490 to Rs 900 per $\mathrm{kg}$ in the domestic market. Average price of ground coffee was Rs 639.09 per $\mathrm{kg}$. The purchased price for $7 \mathrm{~kg}$ fresh cherry was Rs 182. Thus, the processing cost of fresh cherry was altogether Rs 14.84 per kg. Hence, final retail price of fresh cherry was Rs 81.30 per $\mathrm{kg}$ in the form of ground coffee. Marketing margin and producers' share for per kg fresh cherry when it was sold in ground coffee form was Rs 50.46 and 34.00 percent, respectively.

In the domestic market, coffee was sold in the form of roasted beans, too. The price of roasted bean ranged from Rs 480 to Rs 800 per $\mathrm{kg}$. The average price of roasted bean was Rs 597.00 per $\mathrm{kg}$. Final retail price for fresh cherry was Rs 83.05 per $\mathrm{kg}$ in the form of roasted bean. The marketing margin per kg of fresh cherry in this case was found to be Rs 52.88. The producers' share was 32.96 percent.

\section{CONCLUSION}

Coffee produced in all districts was organic. Average variable cost and average return from coffee production were highest in Syangja. Highest gross margin, net profit and benefit cost ratio in Syangja showed that coffee cultivation was more profitable in Syangja. However, higher benefit cost ratio indicated that it was running in profit in other districts too. Number of productive plant was the significant factor affecting production in Kavrepalanchok, Sindhupalchok, Palpa and Syangja. Labor was the significant factor affecting production in Sindhupalchok, Gulmi, Palpa and Syangja. 
Producers, pulper operators, DCPAs, processors and exporters, and retailers were the major actors of coffee marketing. Based on the findings of the study, the following strategies are recommended for organic coffee sector in Nepal: provide loan at cheaper interest rate for production and processing of coffee, training with technical package of coffee cultivation and training for quality processing and management at pulping center.

\section{ACKNOWLEDGEMENTS}

The authors acknowledge to the Global Future Institute (GFI), U.S.A. for complete financial support in time to conduct research.

\section{REFERENCES CITED}

Adhikari, C.M. 2005. World-Trade Organization-WTO and Nepal. Pairabi Prakashan, Ramshahpath, Kathmandu, Nepal.

AEC. 2006. Coffee. Agro Enterprise Center/Federation of Nepalese Chambers of Commerce and Industry, Kathmandu, Nepal.

Agri Business and Trade Promotion Multi Purpose Cooperatives Ltd. 2004. The study report on Identification of Administrative and Policy Constraints that Small Farmers Face in Palpa (Coffee). Submitted to Agro Enterprise Center/Federation of Nepalese Chambers of Commerce and Industry, Kathmandu, Nepal.

Dhakal, B.R. 2004. Coffee Manual. National Tea and Coffee Development Board, New Baneshor, Kathmandu, Nepal.

Dhakal, B.R. 2005. Coffee Manual. National Tea and Coffee Development Board, New New Baneshor, Kathmandu, Nepal.

Khanal, D. 2003. Coffee Production Technology. Bagbani Wadi. Horticulture Center, Kritipur, Nepal. Year 3. Issue 8.

NARC. 2004. Annual Report. National Agricultural Research Council, Khumaltar, Lalitpur, Nepal.

NTCDB. 2008. Tea-A-Tea. National Tea and Coffee Development Board, New Baneshwor, Kathmandu, Nepal.

PSS. 2004. Krishi Sandesh. Postgraduate Student Society, Institute of Agriculture and Animal Science, Rampur, Chitwan, Nepal.

Sarcinelli, O. and E. Ortega. 2004. Emergy Analysis and Bookkeeping Accounting of Conventional and Organic Coffee Production in Brazil. Available: http://www.unicamp.br/fea/ortega/energy/ oscar.pdf. Retrieved: 7 July 2008. 